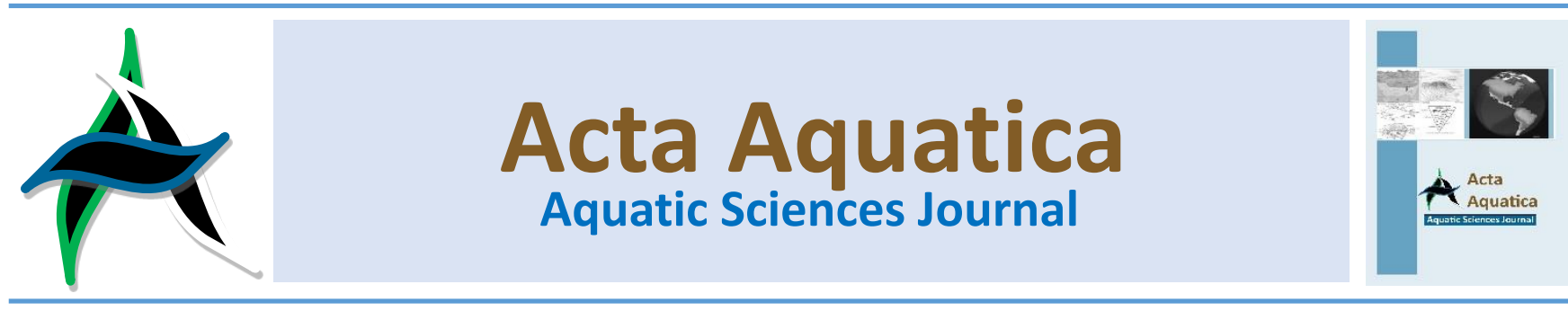

\title{
Morphometric features of topmouth gudgeon Pseudorasbora parva (Temminck \& Schlegel, 1846) in the Hirfanlı Reservoir, Turkey
}

\author{
Semra Benzer ${ }^{a}{ }^{*}$ \\ ${ }^{a}$ Department of Science Education, Gazi University, Turkey
}

\begin{abstract}
The aim of this study was to some morphometric characteristics of Pseudorasbora parva from Hirfanlı Reservoir, Turkey. A morphological analysis of 29 morphometric characters were performed. These characteristics head length; preorbital distance; eye diameter; postorbital distance; head depth; predorsal distance; prepelvic distance; preanal distance; pectoral fin-pelvic fin ( $P$ - $V$ ) distance; pelvic fin- anal fin (V-A) distance; body depth (18 perpendicular); dorsal fin (anterior end)-anal fin distance (Da-A); dorsal fin (posterior end)-anal fin distance (Dp-A); postdorsal distance; postanal distance; caudal (C) peduncle length (dorsal); caudal peduncle length (ventral); caudal peduncle depth; dorsal fin (D) base length; anal fin (A) base fin length; pectoral fin (P) length; pelvic (V) fin length; caudal upper lobe length; caudal fork length; caudal lower lobe length; dorsal fin length; anal fin length; gape. The samples were measured weight to the nearest $0.01 \mathrm{~g}$ and total, fork and standard length to the nearest $0.01 \mathrm{~mm}$. The total length (TL) ranged from $4.10 \mathrm{~cm}$ to $9.30 \mathrm{~cm}$ and body weight ranged from 0.600 to $7.137 \mathrm{~g}$.
\end{abstract}

Keywords: Pseudorasbora parva; topmouth gudgeon; morphometric properties; Hirfanlı Reservoir

\section{Introduction}

Morphometric measurements are widely used to identify differences between fish populations (Cheng et al., 2005). Fish morphology means anatomical design among fish species. Body architecture can be discussed in terms of the characteristic depth, predation style and other swimming specializations required for the survival success of a given species (Hogan, 2007).

The topmouth gudgeon Pseudorasbora parva is a small cyprinid in the freshwaters of Japan, China, Korea and the River Amur. It was described originally from Nagasaki Japan, holotype (Eschemeyer, 2003). Topmouth gudgeon, P. parva (Temmick \& Schlegel, 1842) is a highly invasive species in Europe (Gozlan et al., 2002). It has environmental tolerance to low oxygen, organic pollution, and even concentrations of pesticides that are lethal to other fish species (Allen et al., 2006). The life story flexibility of successful invaders may be also be associated with their potential for great morphological plasticity (Zahorska et al., 2009, Novomeska et al., 2013). P. parva have negative impact on the negative fish fauna via competition spawning area, food and other resources (Ekmekçi et al., 2013).

* Corresponding author: Department of Science Education, Faculty of Education, Gazi University Teknikokullar, Y. Mahalle, Ankara, Turkey Tel: +90.312 .2021608$

e-mail: sbenzer@gazi.edu.tr; sbenzer@gmail.com doi: https://doi.org/10.29103/aa.v7i1.2030
There are many studies on various features of $P$. parva at national and international (Erk'akan, 1984, Wildekamp et al., 1997, Cakic et al., 2004, Ekmekçi \& Kırankaya, 2006; Britton et al., 2007; Boltachev, 2006; Karabanov et al., 2010; Wang et al., 2012; Patimar \& Baensaf, 2012; Huo et al., 2012; Tarkan et al., 2014; Kırankaya et al., 2014; Kapusta et al., 2014; Tarkan et al., 2015; Illhan \& Sarı 2015; Carosi et al., 2016; Benzer et al., 2016; Bakaç et al., 2017; Benzer 2018; Benzer \& Benzer 2019) in the different locations. This paper describes the area where this fish was found and recorded morphometric data of the population in Hirfanlı Reservoir.

\section{Materials and methods}

\subsection{Study area}

The study was carried out in Hirfanlı Reservoir (Fig. 1), which was constructed in 1959, on river Kızılırmak, $70 \mathrm{~km}$ far from the south of Kırıkkale. It is located at $856 \mathrm{~m}$ altitude with a capacity of $7.63 \times 109 \mathrm{~m}^{3}$ and an area of $320 \mathrm{~km}^{2}$. The depth, length and width of the lake are $58 \mathrm{~m}, 90$ and $15 \mathrm{~km}$, respectively. It is $24 \mathrm{~km}$ far from Ankara Kırşehir Highway and $30 \mathrm{~km}$ from Ankara-Adana highway (DSI, 1968).

\subsection{Methodology}

Fish specimens were captured by commercial fisherman from Hirfanlı Reservoir in 2016. The samples were preserved in $4 \%$ formaldehyde solution and transported to the laboratory; weight was measured to the nearest $0.001 \mathrm{~g}$ and total and standard length to the nearest $0.1 \mathrm{~mm}$. 


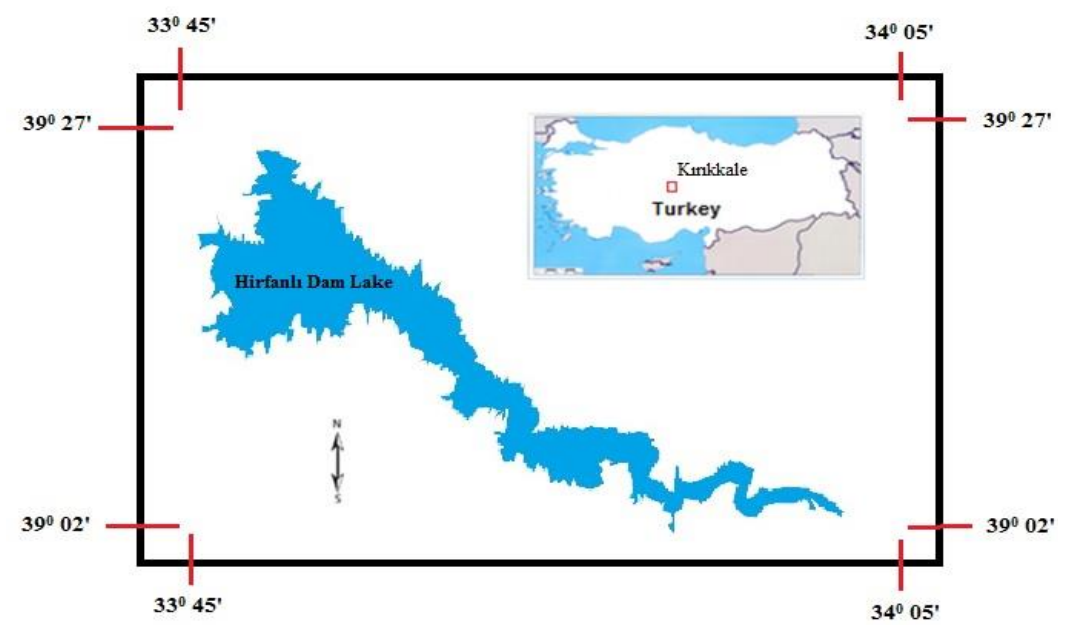

Figure 1. Hirfanlı Reservoir

In total, twenty-nine (29) morphometric characters of samples were measured (Fig. 2). These characteristics were standard length (SL), total length (TL) body weight (W), head length (11-8); preorbital distance (11- '13); eye diameter (1312); postorbital distance (12-8); head depth (15-2); predorsal distance (11-18); prepelvic distance (11-3); preanal distance (11-4); pectoral fin-pelvic fin (P-V) distance (6-3); pelvic finanal fin (V-A) distance (3-4); body depth (18 perpendicular); dorsal fin (anterior end)-anal fin distance (Da-A) (18-4); dorsal fin (posterior end)-anal fin distance (Dp-A) (17-4); postdorsal distance (17-10); postanal distance (7-10); caudal (C) peduncle length (dorsal) (17-14); caudal peduncle length (ventral) (7-5); caudal peduncle depth (14-5); dorsal fin (D) base length (1817); anal fin (A) base fin length (4-7); pectoral fin (P) length (6$20)$; pelvic (V) fin length (3-21); caudal upper lobe length (10$16)$; caudal fork length (10-9); caudal lower lobe length (10-1); dorsal fin length (18-19); anal fin length (4-22); gape (11-23) (Fig.3) (Záhorská et al. 2013).

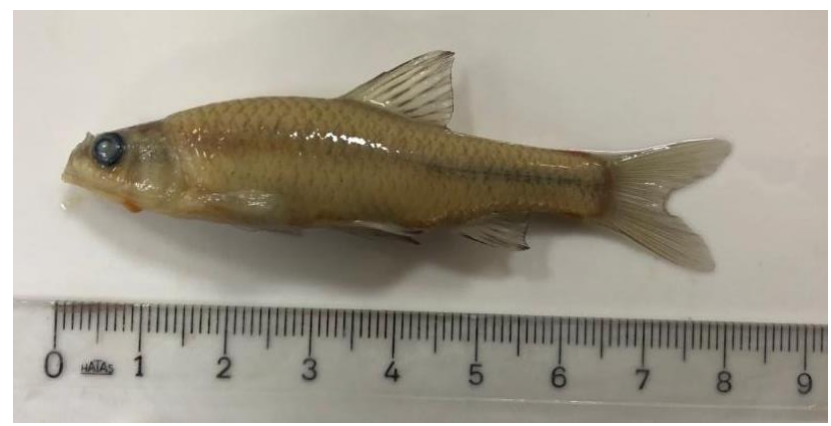

Figure 2. Pseudorasbora parva

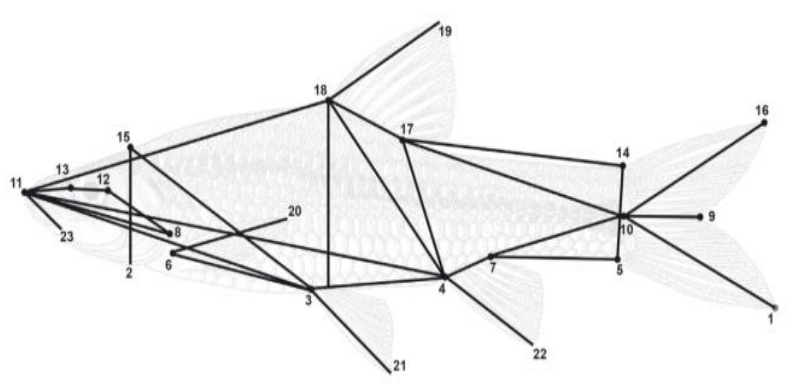

Figure 3. Morphometric characters for distance-based measurements (Záhorská et al., 2013)
Fishermen who hunted for commercial purposes to hunt Atherina boyeri have also been found to hunt Aphanius marassantensis and $P$. parva species in Hirfanlı Reservoir.

\section{Result and discussion}

In this research, some morphometric characters were examined and the minimum, maximum, mean, standard deviation values are given in Table 1 . Measurements and counts of the 25 specimens are given Table 1 . Total lengths and body weights of the examined specimens ranged 4.10 and $9.30 \mathrm{~cm} ; 0.600$ and $7.137 \mathrm{~g}$ respectively.

It appear that both the adult phenotype and the pattern of development in introduced $P$. parva can, in general, be highly influenced by local conditions because the morphology and the ecology presented by an organism have been shown to be directly or indirectly under the influence of the environmental conditions that the organism experiences and its heritable composition (Norton et al., 1995).

In this study were found difference even between population from the other water systems (Table 2). The topmouth gudgeon is considered to be a species with great morphological variability (Kotusz \& Witkowski, 1998, Zhorska et al., 2013). Some of the research work related to P.parva in Turkey and in the world include (TL 27.8 to $58.1 \mathrm{~mm}, 0.4$ to 3.2 $\mathrm{g}$ in Kuchki Pond (Boltachev et al., 2006); TL 4.58-7.50 cm Iran (Esmaeili \& Ebrahimi, 2006); SL 23.42-59.71 mm Slovakia (Zahorska \& Kovac, 2009); SL 18.16 - 67.57 mm, Sur Pond (Zahorska et al., 2010); TL 5.4-8.3 cm Lake Doirani, Lake Mikri Prespa and Lake Volvi (Bobori et al., 2010); TL 3.0-7.2 cm Sirwan River (Hasankhani et al., 2014); TL 18.02-96.24 mm Hirfanlı Reservoir (Kırankaya et al., 2014); TL 5.20-11.0 Marmara Lake (Illhan \& Sarı, 2015); TL 4.6-7.5 Tajan River (Aazami et al., 2015); TL 4.2-9.2 cm Mogan Lake (Benzer et al., 2016); TL 56.75-76.10 mm Gökçeada Dam Lake (Bakaç et al., 2017); TL 4.10-6.80 cm Süreyyabey Dam Lake (Benzer, 2018); TL 2.7-9.2 Hirfanlı Dam Lake (Benzer \& Benzer, 2019).

The difference may be caused by differences in morphological features of the species and habitats. In general, topmouth gudgeon popultions show considerable variation in external morphology, which is not only evident in European populations but also in its native range (Gozlan et al., 2010). It would be expected that populations from different latitudes and/or habitats show significant morphological variability, but differences were also found between populations from the same region (Zahorska et al., 2009). This variability can be expressed not only in the formation of different adult phenotypes but also in the manner with which the phenotypes are achieved. In general, the temperature regime has a considerable influence on life histories and extreme temperatures are known to affect various traits, from morphology (Sumer et al., 2005).

$P$. parva indivuduals prefers wide, varied environments with abundant food sources, in shallow regions and regions with dense vegetation (Kapusta et al., 2008). It was reported that $P$. parva transmits fatal diseas to native fish fauna, limits the reproduction of the endangered native fish species, and influences the decline of native fish species (Ekmekçi \& Kırankaya, 2006). 
Table 1.

Morphometric characteristics of Pseudorasbora parva specimens

\begin{tabular}{|c|c|c|c|c|c|c|c|c|c|}
\hline & Parameters & $\min$ & Max & Average & SD & $\mathrm{Cl}$ & Margin of error & Upper bound & Lower bound \\
\hline 1 & Standard length & 3.400 & 7.200 & 6.502 & 0.929 & 0.364 & 0.068 & 6.866 & 6.138 \\
\hline 2 & Fork length & 3.900 & 8.200 & 7.370 & 1.098 & 0.449 & 0.103 & 7.818 & 6.921 \\
\hline 3 & Total length & 4.100 & 9.300 & 8.176 & 1.227 & 0.481 & 0.118 & 8.657 & 7.695 \\
\hline 4 & Body weight & 0.600 & 7.137 & 5.414 & 1.741 & 0.682 & 0.238 & 6.096 & 4.731 \\
\hline 5 & Head length & 0.900 & 2.100 & 1.500 & 0.242 & 0.095 & 0.005 & 1.595 & 1.405 \\
\hline 6 & Preorbital distance & 0.200 & 1.000 & 0.528 & 0.143 & 0.056 & 0.002 & 0.584 & 0.472 \\
\hline 7 & Eye diameter & 0.200 & 0.500 & 0.384 & 0.080 & 0.031 & 0.001 & 0.415 & 0.353 \\
\hline 8 & Postorbital distance & 0.400 & 1.400 & 0.752 & 0.190 & 0.074 & 0.003 & 0.826 & 0.678 \\
\hline 9 & Head depth & 0.600 & 1.200 & 1.008 & 0.155 & 0.061 & 0.002 & 1.069 & 0.947 \\
\hline 10 & Predorsal distance & 1.900 & 3.800 & 3.320 & 0.492 & 0.193 & 0.019 & 3.513 & 3.127 \\
\hline 11 & Prepelvic distance & 1.800 & 3.800 & 3.300 & 0.465 & 0.182 & 0.017 & 3.482 & 3.118 \\
\hline 12 & Preanal distance & 2.500 & 5.100 & 4.672 & 0.644 & 0.252 & 0.033 & 4.924 & 4.420 \\
\hline 13 & Pectoral fin - pelvic fin distance & 0.900 & 2.000 & 1.632 & 0.261 & 0.102 & 0.005 & 1.734 & 1.530 \\
\hline 14 & Pelvic fin - anal fin distance & 0.700 & 1.900 & 1.528 & 0.270 & 0.106 & 0.006 & 1.633 & 1.422 \\
\hline 15 & Body depth & 0.700 & 2.000 & 1.668 & 0.318 & 0.125 & 0.008 & 1.793 & 1.543 \\
\hline 16 & Dorsal fin (anterior end) - anal fin distance & 1.200 & 2.500 & 2.192 & 0.389 & 0.153 & 0.012 & 2.345 & 2.039 \\
\hline 17 & Dorsal fin (posterior end) - anal fin distance & 0.800 & 2.800 & 1.692 & 0.438 & 0.172 & 0.015 & 1.864 & 1.520 \\
\hline 18 & Postdorsal distance & 1.500 & 3.200 & 2.752 & 0.416 & 0.163 & 0.014 & 2.915 & 2.589 \\
\hline 19 & Postanal distance & 0.700 & 2.500 & 1.584 & 0.358 & 0.140 & 0.010 & 1.724 & 1.444 \\
\hline 20 & Caudal peduncle length (dorsal) & 1.700 & 3.100 & 2.532 & 0.409 & 0.160 & 0.013 & 2.692 & 2.372 \\
\hline 21 & Caudal peduncle length (ventral) & 0.700 & 1.700 & 1.408 & 0.255 & 0.100 & 0.005 & 1.508 & 1.308 \\
\hline 22 & Caudal peduncle depth. & 0.300 & 1.300 & 0.860 & 0.189 & 0.074 & 0.003 & 0.934 & 0.786 \\
\hline 23 & Dorsal fin base length & 0.300 & 1.200 & 0.920 & 0.196 & 0.077 & 0.003 & 0.997 & 0.843 \\
\hline 24 & Anal fin base fin length & 0.400 & 0.900 & 0.628 & 0.172 & 0.067 & 0.002 & 0.695 & 0.561 \\
\hline 25 & Pectoral fin length & 0.500 & 1.200 & 0.992 & 0.191 & 0.075 & 0.003 & 1.067 & 0.917 \\
\hline 26 & Pelvic fin length & 0.500 & 1.500 & 1.092 & 0.214 & 0.084 & 0.004 & 1.176 & 1.008 \\
\hline 27 & Caudal upper lobe length & 1.000 & 1.900 & 1.663 & 0.214 & 0.086 & 0.004 & 1.748 & 1.577 \\
\hline 28 & Caudal fork length & 0.500 & 1.400 & 0.926 & 0.220 & 0.090 & 0.004 & 1.016 & 0.836 \\
\hline 29 & Caudal lower lobe length & 0.800 & 2.000 & 1.636 & 0.335 & 0.131 & 0.009 & 1.767 & 1.505 \\
\hline 30 & Dorsal fin length & 0.700 & 1.900 & 1.528 & 0.242 & 0.095 & 0.005 & 1.623 & 1.433 \\
\hline 31 & Anal fin length & 0.500 & 1.500 & 1.016 & 0.203 & 0.080 & 0.003 & 1.096 & 0.936 \\
\hline 32 & Gape & 0.200 & 0.700 & 0.400 & 0.147 & 0.058 & 0.002 & 0.458 & 0.342 \\
\hline
\end{tabular}

Table 2.

Morphometric measurements of Pseudorasbora parva in literature

\begin{tabular}{|c|c|c|c|c|c|c|c|c|}
\hline \multirow[t]{2}{*}{ Paramaters } & \multicolumn{2}{|c|}{$\begin{array}{c}\text { This Study } \\
\text { (Hirfanlı Reservoir) }\end{array}$} & \multicolumn{2}{|c|}{$\begin{array}{c}\text { Benzer (2018) } \\
\text { (Süreyyabey Dam Lake) }\end{array}$} & \multicolumn{2}{|c|}{$\begin{array}{c}\text { Barkaç et al. (2017) } \\
\text { Gökçeada Dam Lake } \\
\text { (Dam Entrance) }\end{array}$} & \multicolumn{2}{|c|}{$\begin{array}{l}\text { Zahosska et al. (2013) } \\
\text { (Lake Licheńskie) }\end{array}$} \\
\hline & Mean \pm SD & Range & Mean \pm SD & Range & Mean \pm SD & Range & Mean \pm SD & Range \\
\hline Standard Length $(\mathrm{cm})$ & $6.502 \pm 0.929$ & $3.4-7.2$ & $4.388 \pm 0.47$ & $3.50-5.50$ & - & $46.25-62.0$ & $32.77 \pm 15.27$ & $9.26-81.89$ \\
\hline Fork Length $(\mathrm{cm})$ & $7.370 \pm 1.098$ & $3.9-8.2$ & $4.794 \pm 0.53$ & $3.80-6.10$ & - & - & $36.38 \pm 16.82$ & $10.35-86.46$ \\
\hline Total Length $(\mathrm{cm})$ & $8.176 \pm 1.227$ & $4.2-9.2$ & $5.332 \pm 0.57$ & $4.10-6.80$ & - & $56.75-76.1$ & $39.41 \pm 17.63$ & $14.06-89.93$ \\
\hline Body Weight (g) & $5.414 \pm 1.741$ & $0.6-7.137$ & $1.612 \pm 0.56$ & $1.0-3.46$ & & & & \\
\hline \multicolumn{9}{|l|}{ In \% of SL } \\
\hline Head length & $23.07 \pm 3.72$ & $13.84-32.30$ & $25.23 \pm 3.19$ & $20.51-34.18$ & $21.28 \pm 0.24$ & $21.08-21.55$ & $26.49 \pm 2.12$ & $19.63-35.13$ \\
\hline Preorbital distance & $8.12 \pm 2.20$ & $3.08-15.38$ & $24.98 \pm 11.52$ & $4.56-79.76$ & & & $7.59 \pm 0.90$ & $4.78-11.16$ \\
\hline Eye diameter & $5.91 \pm 1.23$ & $3.08-7.69$ & $6.93 \pm 0.98$ & $4.56-9.12$ & & & $7.15 \pm 1.01$ & $4.18-10.86$ \\
\hline Postorbital distance & $11.57 \pm 2.92$ & $6.15-21.53$ & $10.96 \pm 2.16$ & $6.84-15.95$ & & & $11.96 \pm 1.08$ & $8.93-18.13$ \\
\hline Head depth & $15.50 \pm 2.38$ & $9.23-18.46$ & $19.64 \pm 3.35$ & $13.67-29.63$ & & & $20.11 \pm 1.16$ & $15.81-24.69$ \\
\hline Predorsal distance & $51.06 \pm 577$ & $29.22-58.44$ & $53.65 \pm 5.95$ & $45.58-68.37$ & $48.11 \pm 1.46$ & $45.36-50.27$ & $53.20 \pm 2.27$ & $45.11-68.82$ \\
\hline Prepelvic distance & $50.75 \pm 7.15$ & $27.68-58.44$ & $53.05 \pm 8.52$ & $29.63-84.32$ & $48.68 \pm 2.93$ & 46.17-51.89 & $51.53 \pm 2.28$ & $27.65-68.54$ \\
\hline Preanal distance & $71.85 \pm 9.90$ & $38.45-78.44$ & $72.31 \pm 8.71$ & $50.14-97.99$ & $70.14 \pm 3.49$ & $67.7-74.05$ & $70.63 \pm 2.90$ & $26.92-85.94$ \\
\hline Pectoral fin - pelvic fin distance & $25.10 \pm 4.01$ & $13.84-30.76$ & $25.34 \pm 4.24$ & $15.95-34.18$ & & & $25.04 \pm 2.55$ & $10.57-32.87$ \\
\hline Pelvic fin - anal fin distance & $23.50 \pm 4.15$ & $10.77-29.22$ & $21.60 \pm 3.71$ & $13.67-29.63$ & & & $21.48 \pm 2.08$ & $13.89-30.90$ \\
\hline Body depth & $25.65 \pm 4.89$ & $10.77-30.76$ & $26.09 \pm 4.54$ & $20.51-43.30$ & & & $24.86 \pm 1.82$ & $16.50-31.42$ \\
\hline $\begin{array}{l}\text { Dorsal fin (anterior end) - anal } \\
\text { fin distance }\end{array}$ & $33.71 \pm 5.98$ & $18.46-38.45$ & $31.65 \pm 5.90$ & $18.23-47.86$ & & & $29.98 \pm 2.11$ & $19.47-40.37$ \\
\hline $\begin{array}{l}\text { Dorsal fin (posterior end) - anal } \\
\text { fin distance }\end{array}$ & $26.02 \pm 6.74$ & $12.30-43.06$ & $23.38 \pm 5.24$ & $15.95-38.74$ & & & $20.54 \pm 1.75$ & $13.48-28.30$ \\
\hline Postdorsal distance & $42.33 \pm 6.40$ & $23.07-49.22$ & $38.61 \pm 6.91$ & $20.51-52.42$ & & & $39.27 \pm 2.01$ & $26.65-4614$ \\
\hline Postanal distance & $24.36 \pm 5.51$ & $10.77-38.45$ & $23.31 \pm 3.46$ & $15.95-29.63$ & & & $23.73 \pm 1.92$ & $10.07-41.42$ \\
\hline Caudal peduncle length (dorsal) & $38.94 \pm 6.29$ & $26.15-47.68$ & $35.48 \pm 7.25$ & $15.95-50.14$ & & & $37.78 \pm 1.94$ & $27.52-45.66$ \\
\hline Caudal peduncle length (ventral) & $21.65 \pm 3.92$ & $10.77-26.15$ & $20.74 \pm 4.31$ & $2.73-34.18$ & & & $42.87 \pm 2.87$ & $24.26-53.50$ \\
\hline Caudal peduncle depth, & $13.23 \pm 2.91$ & $4.61-19.99$ & $10.55 \pm 2.42$ & $3.65-15.95$ & & & $13.16 \pm 1.02$ & $8.03-17.02$ \\
\hline Dorsal fin base length & $14.15 \pm 3.01$ & 4.6118 .46 & $12.42 \pm 3.42$ & $4.56-27.35$ & $11.66 \pm 1.46$ & $10.05-12.91$ & $13.05 \pm 1.28$ & $7.51-19.94$ \\
\hline Anal fin base fin length & $9.66 \pm 2.65$ & $6.15-13.84$ & $8.04 \pm 2.26$ & $2.28-13.67$ & $7.64 \pm 0.82$ & $6.7-8.23$ & $9.50 \pm 1.21$ & $3.89-16.11$ \\
\hline Pectoral fin length & $15.26 \pm 2.94$ & $7.69-18.46$ & $15.29 \pm 3.62$ & $6.84-22.79$ & & & $14.73 \pm 2.12$ & $5.42-23.13$ \\
\hline Pelvic fin length & $16.79 \pm 3.29$ & $7.69-23.07$ & $14.43 \pm 3.19$ & $9.12-22.79$ & & & $14.88 \pm 1.88$ & $4.06-25.63$ \\
\hline Caudal upper lobe length & $25.58 \pm 3.29$ & $15.38-29.22$ & $23.29 \pm 4.34$ & $13.67-31.91$ & & & $23.91 \pm 2.61$ & $10.63-32.15$ \\
\hline Caudal fork length & $14.24 \pm 3.28$ & $7.69-21.53$ & $13.35 \pm 3.10$ & $9.12-25.07$ & & & - & - \\
\hline Caudal lower lobe length & $25.16 \pm 5.15$ & $12.30-30.76$ & $23.43 \pm 4.08$ & $15.95-31.91$ & & & $23.98 \pm 2.80$ & $7.15-32.51$ \\
\hline Dorsal fin length & $23.50 \pm 3.72$ & $10.77-29.22$ & $21.35 \pm 3.01$ & $11.39-25.07$ & & & $21.94 \pm 1.90$ & $12.15-27.53$ \\
\hline Anal fin length & $15.63 \pm 3.12$ & $7.69-23.07$ & $14.40 \pm 4.08$ & $4.56-25.07$ & & & $13.28 \pm 1.59$ & $8.35-20.12$ \\
\hline Gape & $6.15 \pm 2.26$ & $3.08-10.77$ & $6.24 \pm 2.53$ & $2.28-13.67$ & & & $8.87 \pm 1.74$ & $2.30-14.49$ \\
\hline
\end{tabular}




\section{Conclusion}

This paper describes the area where this fish was found and recorded morphometric data of the population. Findings obtained in this study are very important because the previous studies about the morphometric properties of $P$. parva have not been found. It is considered that the data obtained in this study will also contribute to future studies.

\section{Bibliography}

Aazami, J., Esmaili-Sari, A., Abdoli, A., Sohrabi, H. \& Van Den Brink, P.J., 2015. Length-weight relationships of 14 fish species from Tajan River, Southern Caspian Sea basin, Iran. Iranian Journal of Ichthyology, 2(4): 299-301.

Allen, Y., Kirby, S., Copp, G.H. \& Brazier, M., 2006. Toxicity of rotenone to topmouth gudgeon Pseudorasbora parva for eradication of this non-native species from a tarn in Cumbria, England. Fish Manag Ecol 13: 337-340. doi: 10.1111/j.1365-2400.2006.00499.x

Bakaç, i., Yalçın Özdilek, Ş. \& Ekmekçi, F.G., 2017. First record for invasive Topmouth gudgeon Pseudorasbora parva (Temminck and Schlegel, 1846) from Gökçeada (Çanakkale). Ege Journal of Fisheries and Aquatic Sciences, 34(4): 459-462. doi: 10.12714/egejfas.2017.34.4.14

Benzer, S., 2018. First Record of Topmouth Gudgeon Pseudorasbora parva (Temminck and Schlegel, 1846) in the Süreyyabey Dam Lake, Yeşilırmak Basin, Turkey. Annals of Biological Sciences, 2018, 6 (2):26-29

Benzer, S. \& Benzer, R., 2019. Growth and length-weight relationships of Pseudorasbora parva (Temminck \& Schlegel, 1846) in Hirfanlı Dam Lake: Comparison with traditional and artificial neural networks approaches. Iranian Journal of Fisheries Sciences. DOI:10.22092/ijfs.2018.119889.

Benzer, S., Benzer, R, \& Gül, A., 2016. Artificial neural networks application for biological systems: the case study of Pseudorasbora parva. St. Kliment Ohridski University Press Sofia. Developments in Science and Engineering, Chapter, 49-59.

Bobori, D.C., Moutopoulos, D.K., Bekri, M., Salvarina, I. \& Munoz, A.I.P., 2010. Length-weight relationships for freshwater fishes caught in three Greek lakes. Journal of Biological ResearchThessaloniki, 14: 219-224.

Boltachev, A. R., Danilyuk, O. N., Pakhorukov, N. P. \& Bondarev, V. A., 2006. Distribution and certain features of the morphology and biology of the stone moroco Pseudorasbora parva (Cypriniformes, Cyprinidae) in the waters of Crimea. Journal of Ichthyology, 46(1): 58-63.

Britton, J. R., Davies, G. D., Brazier, M. \& Pinder, A.C., 2007. A case study on the population ecology of a topmouth gudgeon (Pseudorasbora parva) population in the UK and the implications for native fish communities. Aquatic Conservation: Marine and Freshwater Ecosystems, 17(7): 749-759.
Cakic, P., Lenthard, M., Kolarevic, J., Mikovic, B. \& Hegedis, A., 2004. Distribution of the Asiatic Cyprinid Pseudorasbora parva in Serbia and Montenegro. J Fish Biol. 65: 14311434. doi: 10.1111/j.1095-8649.2004.00525.x

Carosi, A., Ghetti, L. \&Lorenzoni, M., 2016. Status of Pseudorasbora parva in the Tiber river basin (Umbria, central Italy) 20 years after its introduction. Knowledge and Management of Aquatic Ecosystem, 417(22): 11. DOI:10.1051/kmae/2016009

Cheng, Q. Q., Lu, D. R. \& Ma, L.., 2005. Morphological differences between close populations discernible by multivariate analysis: a case study of genus Coilia (Teleostei: Clupeiforms). Aquatic Living Resources, 18(2): 187-192.

DSI, 1968. Limminological survey report of Hirfanli Dam Lake, Ankara, Turkey

Ekmekçi, F.G., Kırankaya, Ş.G., Gençoğlu, L. \& Yoğurtçuoğlu, B., 2013. Present Status of Invasive Fishes In Inland Waters of Turkey and Assessment Of The Effects Of Invasion. İstanbul Uni. Journal of Fisheries \& Aquatic Sciences. 28(1): 105-140.

Ekmekçi, F.G. \& Kirankaya, S.G., 2006. Distribution of an invasive fish species, Pseudorasbora parva (Temminck \& Schlegel, 1846) in Turkey. Turkish Journal of Zoology, 30: 329-334.

Erk'akan, F., 1984. Trakya Bölgesinden Türkiye İçin Yeni Kayıt Olan Bir Balık Türü Pseudorasbora parva (Pisces Cyprinidae). Doğa Bilim Dergisi, 8(3): 350-356. (in Turkish)

Eschemeyer, W.N., 2003. The catalog of FishesOn-Line. California Academy of Sciences, USA. :http:/www.calacademy.org/research/ichthyology/catal og/.

Esmaeili, H.R. \&Ebrahimi, M., 2006. Length-weight relationships of some freshwater fishes of Iran. Journal of Applied Ichthyology, 22(4): 328- 329. DOI: 10.1111/j.14390426.2006.00653.x

Gozlan, R. E., Pinder, A. C. \& Shelley, J., 2002. Occurrence of the Asiatic cyprinid Pseudorasbora parva in England. Journal of Fish Biology, 61(1): 298-300.

Hasankhani, M., Keivany, Y., Daliri, M., Pouladi, M. \& Soofiani, N.M., 2014. Length-weight and length-length relationships of four species (Barbus lacerta, Pseudorasbora parva, Squalius lepidus and Oxynoemacheilus angorae) from the Sirwan River, western Iran. Journal of Applied Ichthyology, 30(1): 206207. DOI: 10.1111/jai.12319

Hogan C.M., 2007. Fish morphology. In: Cleveland C.J. (ed.), Encyclopedia of Earth, Washington DC.

Huo, T.B., Jiang, Z.F., Karjan, A., Wang, Z.C., Tang, F.J. \& Yu, H.X., 2012. Length-weight relationships of 16 fish species from the Tarim River, China. Journal of Applied Ichthyology, 28: 152-153. DOI: 10.1111/j.14390426.2011.01899.x 
IIlhan A., Sarı H. M., 2015. Length-weight relationships of fish species in Marmara Lake, West Anatolia, Turkey. Croatian Journal of Fisheries, 73 (1): 30-32.

Kapusta A., Kutsokon Y., Bogacka-Kapusta E., 2014. Comparisons of morphometrics recently established population of topmouth gudgeon (Pseudorasbora parva) from a heated lakes in Poland - Acta Universitatis Prešoviensis, Folia Oecologica 6: 4-8.

Kapusta, A., Bogacka-Kapusta, E., \& Czarnecki, B., 2008. The significance of stone moroko, Pseudorasbora parva (Temminck and Schlegel), in the small-sized fish assemblages in the littoral zone of the heated Lake Licheńskie. Archives of Polish Fisheries, 16(1), 49-62.

Karabanov, D. P., Kodukhova, Y. V., \& Kutsokon, Y. K., 2010. Expansion of stone moroco Pseudorasbora parva (Cypriniformes, Cyprinidae) to waters of Eurasia. Vestn. Zool, 44(2): 115-124.

Kırankaya, Ş.G., Ekmekçi, F.G., Yalçın Özdilek, Ş., Yoğurtçuoğlu, B. \& Gençoğlu, B., 2014. Condition, lengthweight and length-length relationships for five fish species from Hirfanli Reservoir, Turkey. Journal of Fisheries Sciences, 8(3): 208-213. DOI: 10.3153/jfscom.201426

Kotusz, J., \& Witkowski, A., 1998. Morphometrics of Pseudorasbora parva [Schlegel, 1842] [Cyprinidae: Gobioninae], a species introduced into the Polish waters. Acta Ichthyologica et Piscatoria, 2(28): 3-14.

Norton, S. F., Luczkovich, J. J., \& Motta, P. J., 1995. The role of ecomorphological studies in the comparative biology of fishes. In Ecomorphology of fishes (pp. 287-304). Springer, Dordrecht.

Novomeská A., Katina S., Copp G.H., Pedicillo G., Lorenzoni M., Pompei L., Cucherousset J., \& Kováč, 2013. Morphological variability of black bullhead Ameiurus melas in four non-native European populations. Journal of Fish Biology. 82: 1103-1118.

Patimar, R., \& Baensaf, S., 2012. Morphology, growth and reproduction of the non-indigenous topmouth gudgeon Pseudorasbora parva (Temminck et Schlegel, 1846) in the wetland of Alma-Gol, northern Iran. Russian Journal of Biological Invasions, 3(1): 71-75.

Sumer, S., Kovac, V., Povz, M. \& Slatner, M., 2005. External morphology of Slovenian population of pumpkinseed Lepomis gibbosus (L.) from a habitat with extreme thermal conditions. J Appl Ichthyol 21: 306-311.

Tarkan, A.S., Ekmekçi, F.G., Vilizzi, L. \& Copp, G. H., 2014. Risk screening of nonnative freshwater fishes at the frontier between Asia and Europe: first application in Turkey of the fish invasiveness screening kit. Journal of Applied Ichthyology, 30: 392-398.

Tarkan, A.S., Marr, S.M. \& Ekmekçi F.G., 2015. Non-native and translocated freshwater fish species in Turkey. Fishmed 2015.003: 1-28.

Wang, T., Wang, H.S., Sun, G.W., Huang, D. \& Shen, J.H., 2012. Length-weight and length-length relationships for some
Yangtze River fishes in Tian-e-zou Oxbow, China. Journal of Applied Ichthyology, 28: 660-662. DOI:10.1111/j.1439- 0426.2012.01971.x

Wildekamp R.H., Van Neer, W., Küçük, F. \& Ünlüsayın M., 1997. First record of the Asiatic gobinid fish Pseudorasbora parva from the Asiatic part of Turkey, Journal of Fish Biology 51: 858-861.

Záhorská, E., Kováč, V., 2009. Reproductive parameters of invasive Stone moroko Pseudorasbora parva (Temminck and Schlegel, 1846) from Slovakia. J App Ichthyol 25: 466-469.

Záhorská, E., Kováč, V. \& Katina, S., 2010. Age and growth in a newly established invasive population of topmouth gudgeon. Central European Journal of Biology, 5(2): 256261. DOI:10.2478/s11535-010-0002-8

Záhorská, E., Kováč, V., Falka, I., Beyer, K., Katina, S., Copp, G. H., \& Gozlan, R. E., 2009. Morphological variability of the Asiatic cyprinid, topmouth gudgeon Pseudorasbora parva, in its introduced European range. Journal of Fish Biology, 74(1): 167-185.

Záhorská, E., Balážová, M., \& Šúrová, M., 2013. Morphology, sexual dimorphism and size at maturation in topmouth gudgeon (Pseudorasbora parva) from the heated Lake Licheńskie (Poland). Knowledge and Management of Aquatic Ecosystems, 411(7). 